\title{
Evolutionary development of energy efficiency in the context of the national carbon-free economic development
}

\author{
Yevheniia Ziabina ${ }^{1}$, Tetyana Pimonenko ${ }^{1, *}$, Oleksii Lyulyov ${ }^{1}$, Yana $\mathrm{Us}^{1}$, \\ and Dmytro Proshkin ${ }^{2}$ \\ ${ }^{1}$ Sumy State University, Department of Marketing, 2, Rymskogo-Korsakova St, 40007 Sumy, \\ Ukraine \\ ${ }^{2}$ Procter\&Gamble, 13/5A, Naberezhno-Khreschatytska St, 04070 Kyiv, Ukraine
}

\begin{abstract}
This research aims to analyse the evolutionary development of the scientific treatises devoted to the national economic energy efficiency. To attain the paper's goal, this study is carried out in the following logical sequence: 1) identification and generation of the necessary relevant data: 2) analysis of keywords co-occurrence to determine the promising research areas on energy efficiency. The authors used keywords "energy policy", "energy efficiency", "sustainable development" to generate the relevant study sample. Thus, the study sample consists of 48,888 publications indexed by the scientometric databases Scopus and Web of Science. The study period is 2000-2020. Visualization of the bibliometric analysis results concerning the national economic energy efficiency management was conducted using the VOSviewer software v.1.6.10. The co-occurrence network map identified the six stages of evolutionary development of scientific treatises on the national economic energy efficiency. Besides, the authors applied Google Trends tools to analyse 2,172 internet search queries regarding the social concern in energy efficiency. In the study, the authors conclude that the scientific society has not yet reached a consensus in identifying key determinants of energy efficiency under the national economy transition to a carbon-free development model. The research results can be helpful for scholars investigating the determinants of developing the national economic energy efficiency.
\end{abstract}

\section{Introduction}

The development of an energy efficiency roadmap of the national economy has flourished since the last decade. In turn, many Ukrainian and foreign scholars have cooperated to explore energy efficiency and the critical determinants influencing the national economic energy efficiency.

The analysis of analytical reports by the American Council for an Energy-Efficient Economy and several research centres [1-5] indicated the correlation between the national

* Corresponding author: tetyana pimonenko@econ.sumdu.edu.ua 
economic energy efficiency and the energy savings potential, the investment attractiveness, and the economic impact on the environment.

In the papers $[8,7]$, the authors conducted the bibliometric analysis of existing treatises devoted to renewable energy and energy efficiency. Therefore, the findings revealed new directions for national economic decarbonization [9] raise by energy efficiency growth under simultaneous development of alternative and environmentally friendly fuels.

It is advisable to consider the general energy efficiency trends concerning the country's GDP [10]. Thus, in the papers $[10 ; 11]$, the researchers developed the integrated energy efficiency indices considering the IDA method [10] and the energy policy asynchrony in Ukraine and the EU countries [11].

Besides, it stands to mention the scientific publications in the field of resource-saving activities [12] and socio-ecological responsibility [12-17]. Notably, in the study [16], the findings indicated the environmental and social entrepreneurship development to the sustainable development of the national economy.

On the other hand, more scientists investigate the green bond markets, investments [1522], decarbonized financial markets [3; 22], and energy-efficient (carbon-free) innovations $[17,23-28]$. It is worth highlighting that these scientific treatises are a strong background for further analytical research in green competitiveness as a crucial vector of green business development in Ukraine and the world [29-31]. Besides, it contributes to reforming and building a new green (environmental) taxation [32], which would reduce the tax burden on green activities [33].

Several scientists studied the development of the smart grid [34-36], environmental management, and green marketing (branding) [37-38] as crucial tools for improving the national economic energy efficiency in the process of carbon-free development.

Notably, a detailed analysis of the preconditions for the national economic energy efficiency indicated that many countries reset their priorities in the energy sector development nowadays. They actively implement the reforms to modernize and re-profile the direction of energy production. Thus, the mentioned above indicates the necessity to monitor the energy system state and the environmental situation in the country [40]. The findings showed that the most promising research areas were alternative energy sources and carbon-free economic development [41-43].

Indeed, the EU countries showed progress in implementing the critical vector under the National Energy Efficiency Action Plans for 2007-2020 (The 20-20-20 Goals) [45]. However, there is a significant gap in Ukraine. The share of renewable energy sources in the final energy consumption has reached only $11 \%$, while the level of energy efficiency has increased by $9 \%$. Moreover, endorsed to the Paris Climate Agreement [46], Ukraine has targeted $40 \%$ CO2 emissions reduction by $40 \%$ by 2030 compared to 1990 . Figure 1 shows the dynamics of CO2 emissions per capita in Ukraine and the EU from 2000 to 2020.

Figure 1 demonstrates the insignificant fluctuations in the $\mathrm{CO} 2$ emissions in many countries. In turn, in Ukraine, the CO2 emissions decreased by 7\% in 2020 compared to 2014, while the minimal level of CO2 emission was in 2015 (4,984 t/capita). It stands to mention that this reduction resulted from political and territorial changes in the country and extensive industrial shutdown.

It bears noting that the statistical data analysis indicates that Ukraine would not reach a $40 \%$ reduction in $\mathrm{CO} 2$ emissions, especially during the current crisis.

For studying the economic energy efficiency, this research involved the world country ranking of energy efficiency by a non-profit organization - the American Council on Energy Efficiency [2]. Figure 2 shows the results of the world country ranking of energy efficiency by economic sectors. 


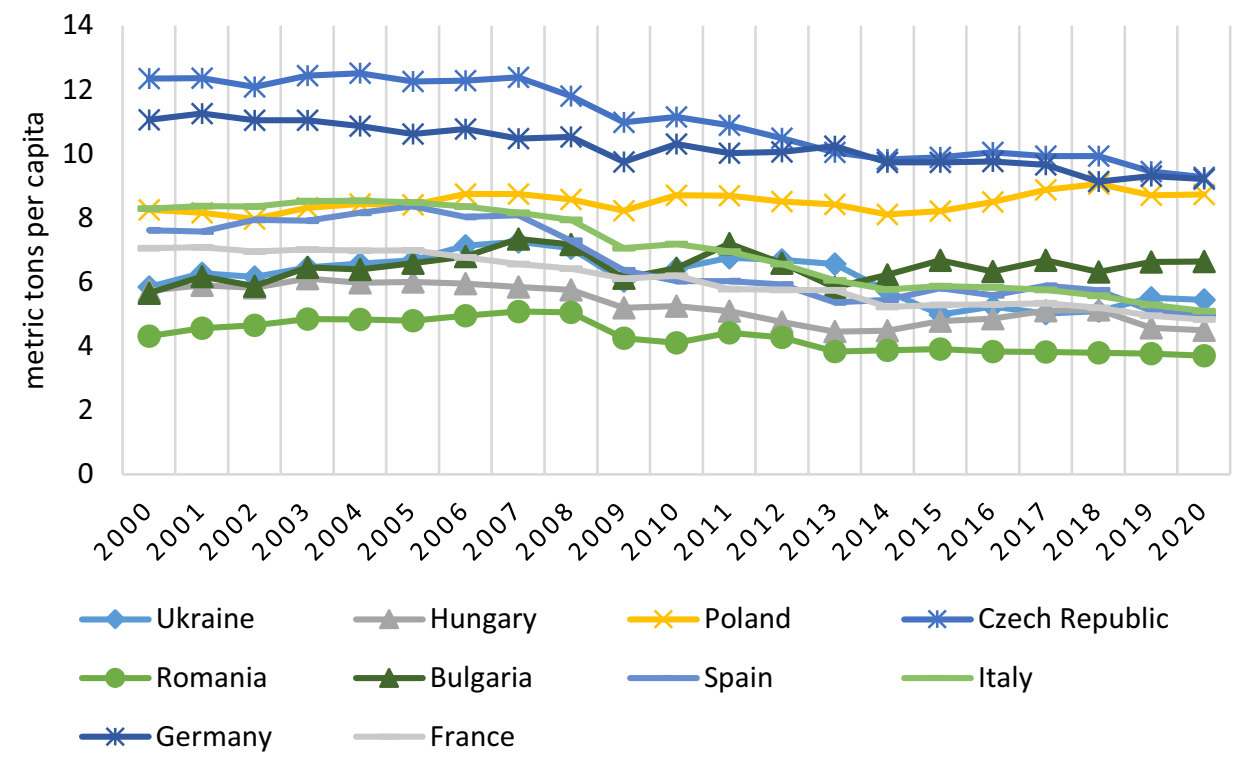

Fig. 1. Dynamics of CO2 emissions per capita in Ukraine and the EU (2000 -2020).

Source: developed by the authors based on [47].

According to the rating mentioned above, the highest score for each item is 25 points. Herewith, France (17.5) and Italy (17) have the highest level of energy efficiency in the transport system. In turn, it is almost half as lower (8.5) in Ukraine, which is caused by the slow introduction and modernization of electric vehicles in the public auto park.

On the other hand, the highest level of industrial energy efficiency was in Japan (21.5), Italy, and Germany (20.5). In Ukraine, this value reached 13 points, which was better than in Poland (10). Indeed, the assessment of energy efficiency rating allows determining the current industries' energy efficiency, the level of exploration of energy-saving technologies, closed cycles in production, and rational and intensive use of resources, etc.

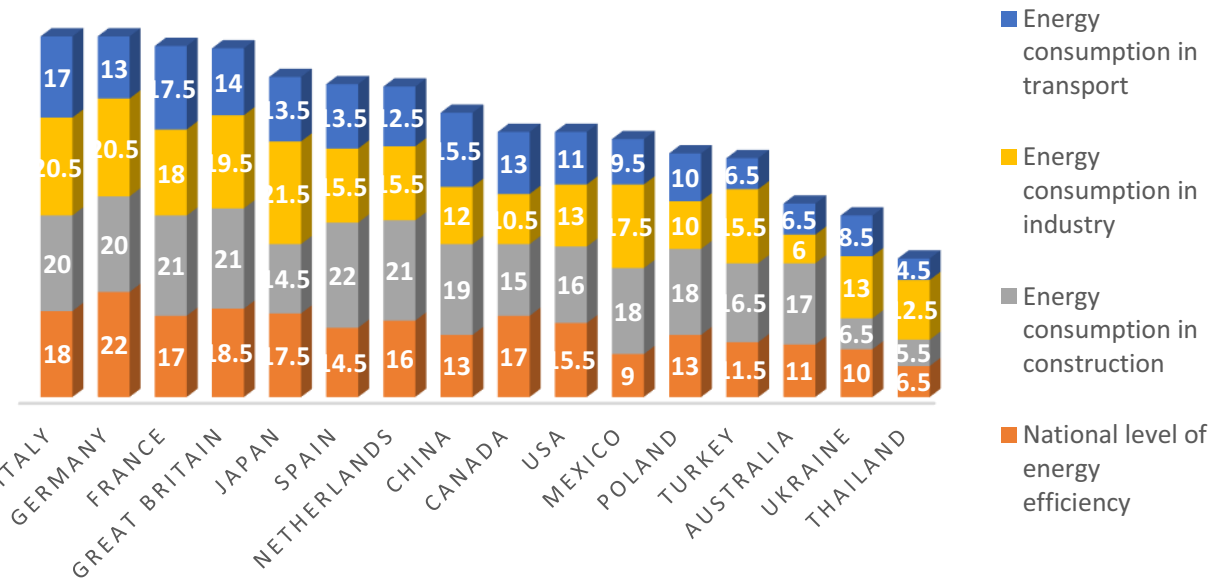

Fig. 2. The world country ranking of energy efficiency by economic sectors (2017-2018).

Sources: developed by the authors based on [2]. 
Figure 2 demonstrates that Ukraine has the worst score in the construction sector compared to other industries (6.5). In turn, the best score was in Spain (22) and France, Great Britain, and the Netherlands (21). The lowest score was recorded in Thailand (5.5). Notably, low energy efficiency in the construction industry of Ukraine is caused by a significant proportion of energy-inefficient buildings. Moreover, Ukraine is only in the initial stage of implementing energy-efficient and European standards in construction.

The overall leading positions of the economic energy-efficient ranking were in Germany (22), Great Britain (18.5), and Italy (18). Notably, Ukraine ranked 19th, while it is ahead of Brazil, Thailand, South Africa, the United Arab Emirates, and Saudi Arabia.

\section{Materials and Methods}

This paper was conducted in several stages investigating scientific treatises devoted to developing the national economic energy efficiency management. The first study stage is aimed to identify and generate the necessary relevant data in the scientometric databases Scopus and Web of Science and the internet search engine Google applying Google Trends tools.

The second stage provided the co-occurrence analysis to determine the promising research areas on energy efficiency. Generating the study sample was delivered using the keywords "energy policy", "energy efficiency", "sustainable development", which resulted in the study sample of 48,888 publications and 21,725 search queries.

To visualize the findings, the VOSviewer software tool was used. It allowed creating the network maps of keyword co-occurrence identifying the research areas in the economic energy efficiency. Notably, the visualized network map consists of circles that differ by size and colour, with a particular colour indicating the cluster. The larger the circle is, the higher is the item occurrence in the publications analysed. Besides, each circle has links with others. The longer link means the weaker strength between the two items.

\section{Results and discussions}

At the first stage, the findings on the analysis of publications indexed by Scopus and Web of Science have showed the growing publication activity on energy efficiency since 2014. Thus, 2014 is a turning point in the growing scientific involvement in studying energy efficiency worldwide. Besides, the number of Google searches increased. It allowed assuming the social concern growth on developing energy efficiency.

In the second stage of this study, the interdisciplinary relationships of publications on the national economic energy efficiency were clustered. Therefore, the keyword co-occurrence analysis identified six interdisciplinary clusters of research on energy efficiency under the national economy transition to the carbon-free model. Figure 3 visualizes these findings.

Thus, the obtained results showed that the most significant cluster (red) could be named "The government regulation of the energy sector". This cluster consists of 309 terms covering the aspects of government energy efficiency regulation. Besides, it stands to mention the keyword "energy policy", whose frequency of co-occurrence in the study sample is 2,563 , while the link strength is 915.

The second, green cluster, "Sustainable development of the national economic energy sector", combines 188 terms related to the study of sustainable development in the energy sector. In this cluster, the co-occurrence frequency of the keyword "sustainable development" is 2,463 , while the link strength is 915 .

The third, blue cluster, "Energy sector influence on the environment", combines 182 terms related to the environmental impact issues from the energy sector. The main keyword 
in the cluster is "fossil fuel". The co-occurrence frequency among the investigated scientific publications is 633 , with the link strength being 865 .

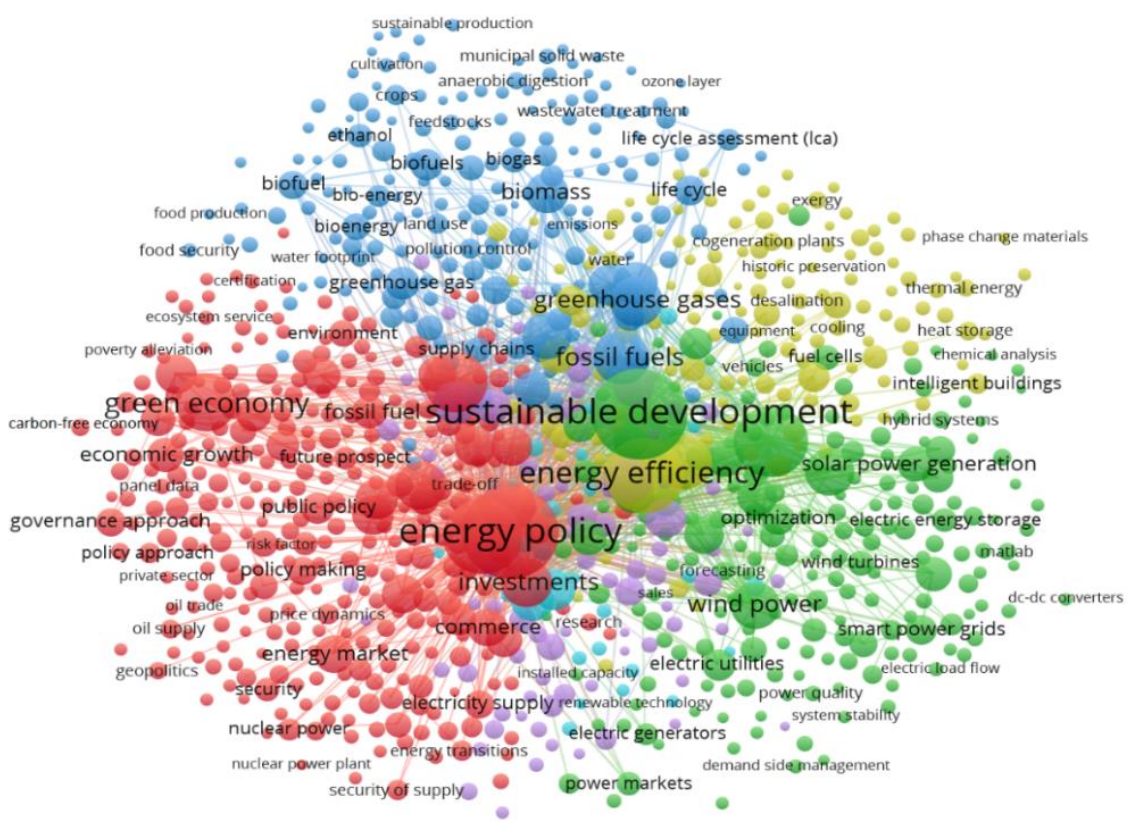

Fig. 3. The network map of the interdisciplinary relationships among the publications devoted to the national economic energy efficiency.

Sources: developed by the authors using VOSviewer software tools.

The yellow cluster, "Tools for developing the national economic energy efficiency", combines 134 terms. This cluster indicates the broad scientific concern in investigating the practical tools for enhancing the national economic energy efficiency. The keyword "energy efficiency" has the high co-occurrence frequency of 1,528, while the link strength is 911 .

The fifth, purple cluster, "Green technologies in developing the national economic energy efficiency", comprises 80 terms. This cluster's main direction is to determine the influence of green technologies implementation on improving the national economic energy efficiency. Notably, the keyword "sustainable energy" mainly appeared. The co-occurrence frequency is 457 , while the link strength is 801 .

Finally, the sixth, cyan cluster, "Smart energy networks in the national economic energy efficiency", combines 27 terms related to investigating smart energy networks' role in the national economic energy efficiency. The co-occurrence frequency of the keyword "smart grids" is 325, and the link strength is 695 .

Figure 3 shows the strong interconnection between investigated clusters. Therefore, the mentioned above confirms the interdisciplinary nature of studies devoted to the national economic energy efficiency.

On the other hand, Figure 4 visualizes the network map of evolutionary development of the research directions in the national economic energy efficiency under sustainable and carbon-free development.

The obtained results of the bibliometric analysis provided by VOSviewer v.1.6.10 allowed identifying and visualizing six stages of evolution of the investigated issue.

Thus, the first stage lasts until 2013. During this period, the main research direction was studying the problems of the energy sector of the national economy and the negative impact 
of greenhouse gas emissions on the environment. In this case, it stands to mention the scientists such as Henley N.D., McGregor P.G., Suels J.K., Terner K. [48], and others [5].

The second stage bore a date from 2013 to 2014. In this period, the scientists primarily investigated energy-saving as a new vector of state policy in ensuring the energy security of the national economy.

The third stage was from 2014 to 2015. During this period, the studies aimed at investigating the determinants of the national economic energy efficiency growth to achieve sustainable development goals. In this research direction, it is worth mentioning the scientists Gilleo A., Chittum A., Farley K., Neubauer M., Novak S., Ribeiro D., Vaidyanatan S. [1].

The fourth stage dated from 2015 to 2016. Herewith, the Ukrainian and foreign scientists [49] focused on developing the tools for green energy promotion and assessing the efficiency of renewable energy sources in the national economic energy efficiency growth.

The fifth stage bore a date from 2016 to 2017. The scientists [50] mainly studied the energy services, the green investment role in energy-efficient projects, etc.

Finally, the sixth stage began in 2017. The results showed that more scientists investigate the determinants of energy efficiency under the transition to a carbon-free model of the national economy $[12 ; 51-118]$.

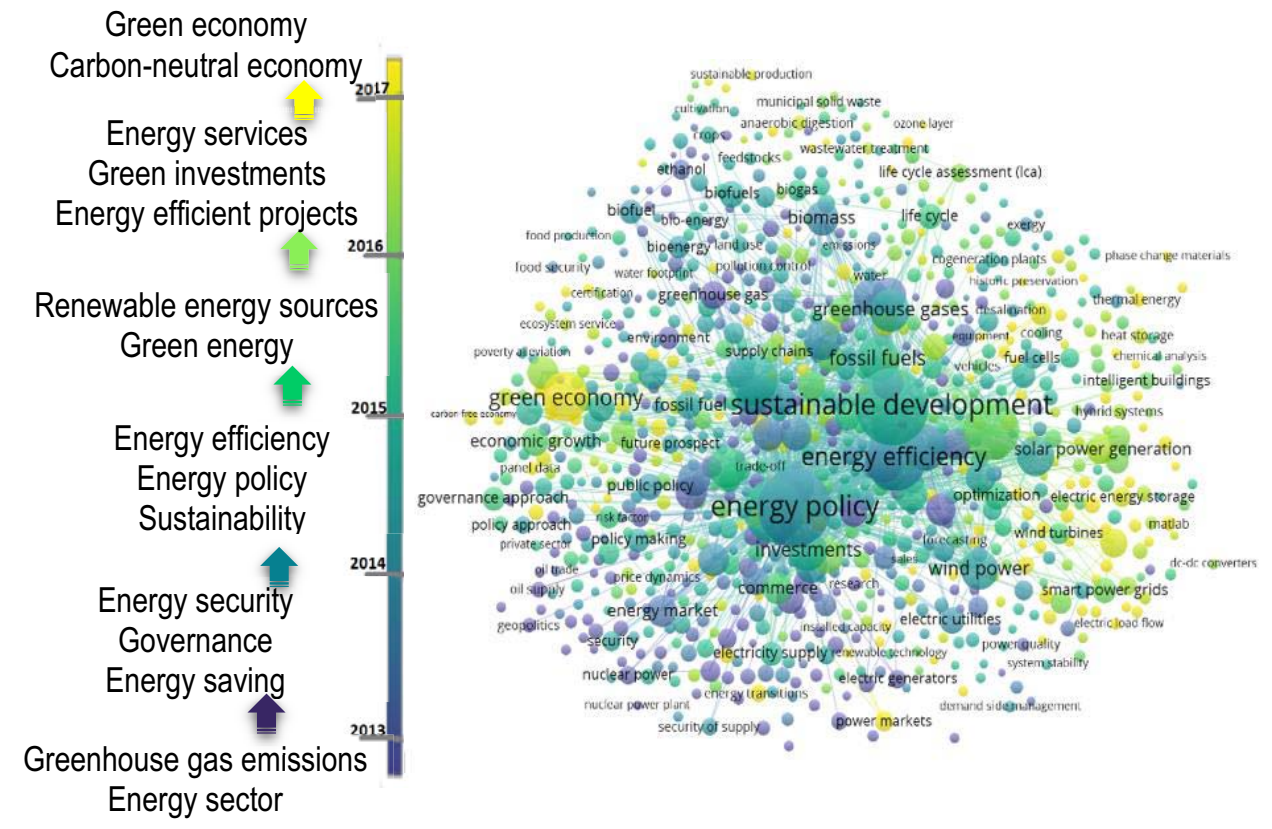

Fig. 4. The evolutionary development network map of research focused on national economic energy efficiency under sustainable and carbon-free development.

Sources: developed by the authors using VOSviewer software.

Therefore, the obtained results indicate the significant research interest in investigating the development patterns of managing the national economic energy efficiency. Moreover, the findings identified the prerequisites for developing an influential scientific school exploring the impact of energy efficiency in the national carbon-free economic development. 


\section{Discussion and conclusion}

This paper provides a bibliometric analysis on developing the management patterns of the national economic energy efficiency. Using VOSviewer software v. 1.6 .10 allowed identifying and visualizing the dynamics of scientific research devoted to the national energy efficiency development. Thus, six main stages were determining the national energy efficiency development. Thus, the first one combines the scientific documents published until 2013. The main research direction was to identify the problems in the national energy sector. On the second stage dated from 2013 to 2014, the scientists mainly considered energy conservation as a new vector of state policy to ensure the energy security of the national economy. Then, from 2014 to 2015, the relevant research direction was the determinants of national energy efficiency development in achieving sustainable development goals. The green energy instruments in enhancing the national economic energy efficiency were investigated from 2015 to 2016 . Consequently, the research on attracting green investment in energy-efficient projects were relevant from 2016 to 2017. Finally, since 2017 the main research direction aimed at investigating the determinant to increase energy efficiency under the transition to the national carbon-free economy.

Acknowledgements: This research was funded by the grants from the National Research Foundation of Ukraine (0120U104807); the Ministry of Education and Science of Ukraine (0121U100468; 0120U102002).

\section{References}

1. A. Gilleo, A. Chittum, K. Farley, M. Neubauer, S. Nowak, D. Ribeiro,

S. Vaidyanathan, The 2015 state energy efficiency scorecard. American Council for an Energy-Efficient Economy (2015, October)

2. American Council on Energy Efficiency (2021). Retrieved from https://www.aceee.org/

3. A. Teletov, S. Teletova, N. Letunovska. Periodicals of Engineering and Natural Sciences, 7(2), 458-465 (2019).

4. R. Miskiewicz, Energies, 13(22), 6106 (2020)

5. H. C. Granade, J. Creyts, A. Derkach, P. Farese, S. Nyquist, K. Ostrowski, Unlocking energy efficiency in the US economy. McKinsey \& Company (2009)

6. A. Rosokhata, M. Minchenko, L. Khomenko, O. Chygryn. Procedings of 1st Conference on Traditional and Renewable Energy Sources: Perspectives and Paradigms for the 21st Century (TRESP 2021), Prague, Czech Republic, Edited by Strielkowski, W.; E3S Web of Conferences, Volume 250

7. L. Saher, L. Syhyda, O. Korobets, T. Berezianko. Paper presented at the E3S Web of Conferences, , 234 doi:10.1051/e3sconf/202123400011

8. Ye. Ziabina, Ye. Kovalenko, SocioEconomic Challenges, 5(1), 117-132 (2021)

9. A. Artyukhov, I. Volk, T. Vasylieva, S. Lyeonov, The role of the university in achieving SDGs 4

10. B. W. Ang, Energy policy, 34(5), 574-582 (2006)

11. Y. Ziabina, Determinants of energy efficiency of the national economy (Doctoral dissertation, Sumy State University (2021)

12. O. Chygryn, International Journal of Ecology and Development, 31(3), 42-59 (2016).

13. I. Mačaitytè, G. Virbašiūtè, Business Ethics and Leadership, 2(1), 6-13 (2018) 
14. Y. Ziabina, Determinants of energy efficiency of the national economy (Doctoral dissertation, Sumy State University (2021)

15. G. Keliuotytè-Staniulènienè, K. Daunaravičiūtè, Institutions and Risks, 5(1), 50-60 (2021)

16. L. Starchenko, Ya. Samusevych, K. Demchuk, Business Ethics and Leadership, 5(1), 118-126 (2021)

17. V. Panchenko, Yu. Harust, Ya. Us, O. Korobets, V. Pavlyk, Marketing and Management of Innovations, 1, 256-264 (2020)

18. R. Vanickova, Marketing and Management of Innovations, 2, 56-67 (2020)

19. T. Vasilyeva, O. Kuzmenko, V. Bozhenko, O. Kolotilina, Assessment of the dynamics of bifurcation transformations in the economy, in Proceedings of the CEUR Workshop Proceedings, 2422, 134-146 (2019)

20. V. Pavlyk, Financial Markets, Institutions and Risks, 4(1), 117-123 (2020)

21. A. El Amri, R. Boutti, S. Oulfarsi, F. Rodhain, B. Bouzahir, Financial Markets, Institutions and Risks, 4(4), 31-44 (2020)

22. M. Taliento, A. Netti, Business Ethics and Leadership, 4(4), 123-131 (2020)

23. S. Kolosok, I. Myroshnychenko, L. Zakharkina, Open data in electrical energy balancing of ukraine: Green deal and security aspects, in Proceedings of the CEUR Workshop Proceedings, 2732, 270-281 (2020)

24. H. Dzwigol, M. Dzwigol-Barosz, Academy of Strategic Management Journal, 19(5), 17 (2020)

25. H. Dzwigol, M. Dzwigol-Barosz, Z. Zhyvko, R. Miskiewicz, H. Pushak, Journal of Security and Sustainability Issues, 8(3), 307-317 (2019)

26. Y. Kharazishvili, A. Kwilinski, O. Grishnova, H. Dzwigol, Sustainability, 12(21), 8953 (2020)

27. S. Kolosok, V. Dementov, S. Korol, O. Panchenko, Journal of Applied Economic Sciences, 13(8), 2375-2384 (2018)

28. T. A. Vasylieva, V. O. Kasyanenko, Actual Problems of Economics, 144(6), 50-59 (2013)

29. O. Chygryn, A. Rosokhata, O. Rybina, N. Stoyanets, Green competitiveness: The evolution of concept formation, in Proceedings of the E3S Web of Conferences, 234 (2021)

30. A. Rosokhata, O. Rybina, A. Derykolenko, V. Makerska. Research in World Economy, 11 (4), 42-52 (2020).

31. A. Bondarenko, L. Zakharkina, L. Syhyda, L. Saher. International Journal of Sustainable Development and Planning, 15(4), 439-449 (2020). doi:10.18280/ijsdp.150404

32. T. Vasylieva, V. Machová, A. Vysochyna, J. Podgórska, Y. Samusevych, Journal of International Studies, 13(4), 273-285 (2020)

33. Y. Hakimova, Y. Samusevych, S. Alijanova, E. Guluzade, Marketing and Management of Innovations, 1, 312-323 (2021)

34. A. Vorontsova, T. Vasylieva, Y. Bilan, G. Ostasz, T. Mayboroda, Administratie Si Management Public, 2020(34), 6-26 (2020)

35. H. S. Andrade, G. Loureiro, Business Ethics and Leadership, 4(2), 86-95 (2020)

36. I. Vakulenko, L. Saher, L. Syhyda, S. Kolosok, A. Yevdokymova, The first step in removing communication and organizational barriers to stakeholders' interaction in 
Smart Grids: A theoretical approach, in the Proceedings of E3S Web of Conferences, 234, $00020(2021)$

37. I. Didenko, K. Volik, T. Vasylieva, S. Lyeonov, N. Antoniuk, Migration, environment, and country safety: Analysis of touchpoints, in Proceedings of the E3S Web of Conferences, 202 (2020)

38. N. Letunovska, L. Saher, T. Vasylieva, S. Lieonov. Paper presented at the E3S Web of Conferences, 250 (2021).

39. S. Kolosok, I. Myroshnychenko, H. Mishenina, I. Yarova, Proceedings of the E3S Web of Conferences, 234 (2021)

40. A. Donlagić, B. Moskalenko, SocioEconomic Challenges, 4(4), 151-159 (2020)

41. I. Didenko, K. Volik, T. Vasylieva, S. Lyeonov, N. Antoniuk, Proceedings of the E3S Web of Conferences, 234 (2021)

42. R. Boutti, Ad. El. Amri, F. Rodhain, Financial Markets, Institutions and Risks, 3(1), 18-29 (2019)

43. A. Kasych, M., Vochozka. Theoretical and methodical principles of managing enterprise sustainable development. Marketing and Management of Innovations, 2, 298-305. (2017). 10.21272/mmi.2017.2-28

44. Y. Bilan, P. Srovnalã-KovÃi, J. Streimikis, S. Lyeonov, I. Tiutiunyk, Y. Humenna, International Journal of Global Environmental Issues, 19(1-3), 196-216 (2020)

45. Green Paper of the Commission of the European Communities: European Strategy for Sustainable, Competitive and Secure Energy (08.03.2006) Retrieved from https://zakon.rada.gov.ua/laws/show/994_713\#Text

46. Law of Ukraine On Ratification of the Paris Agreement. Vidomosti Verkhovnoi Rady, 35, 595 (2016) Retrieved from https://zakon.rada.gov.ua/laws/show/1469-19\#n2

47. European Statistical Office (2021). Retrieved from: https://ec.europa.eu/eurostat/statistics-explained/index.php/Electricity_price_statistics

48. N. D. Hanley, P. G. McGregor, J. K. Swales, K. Turner, Renewable Energy, 31(2), 161-171 (2006)

49. T. Shevchenko, I. Koblianska, L. Saher, Journal of Environmental Management and Tourism, 7(3), 361-369 (2016)

50. K. Pająk, O. Kvilinskyi, O. Fasiecka, R. Miskiewicz, Economics and Environment, 2(61), 122-138 (2017)

51. O. Komelina, S. Shcherbinina, Marketing and Management of Innovations, 1, 382-390 (2018)

52. T. Vasylieva, V. Pavlyk, Y. Bilan, G. Mentel, M. Rabe, Energies, 14(5) (2021)

53. Y. Samusevych, A. Vysochyna, T. Vasylieva, S. Lyeonov, S. Pokhylko. Proceedings of the E3S Web of Conferences, 234 (2021)

54. Y. Ziabina, T. Pimonenko, L. Starchenko, SocioEconomic Challenges, 4(4), 160-174 (2020)

55. He. Shuquan, Business Ethics and Leadership, 3(4), 43-48 (2019)

56. S. Cyfert, A. Chwiłkowska-Kubala, W. Szumowski, R. Miśkiewicz, PLoS ONE, 16(4), e0249724 (2021)

57. B. Czyżewski, A. Matuszczak, R. Miskiewicz, Technological and Economic Development of Economy, 25(1), 82-102 (2019)

58. H. Dzwigol, M. Dzwigol-Barosz, R. Miskiewicz, A. Kwilinski, Entrepreneurship and Sustainability Issues, 7(4), 2630-2644 (2020) 
59. E. Gross-Golacka, M. Kusterka-Jefmanska, R. Miskiewicz, B. Jefmanski, A. Rzepka, T. Kupczyk, European Research Studies Journal, XXIV(2B), 410-429 (2021)

60. L. Hrytsenko, I. Boiarko, O. Tverezovska, J. Polcyn, R. Miskiewicz, Marketing and Management of Innovations, 2, 155-165 (2021)

61. R. Miskiewicz, Polityka Energetyczna, 21(2), 49-62 (2018)

62. R. Miskiewicz, Virtual Economics, 2(2), 37-47 (2019)

63. R. Miskiewicz, Marketing and Management of Innovations, 3, 371-381 (2020)

64. R. Miśkiewicz, Journal of Risk and Financial Management, 14(2), 59 (2021)

65. R. Miśkiewicz, R. Wolniak, Sustainability, 12(14), 5776 (2020)

66. O. Prokopenko, R. Miskiewicz, Entrepreneurship and Sustainability Issues, 8(2), 269284 (2020)

67. A. Rzepka, R. Borowiecki, R. Miskiewicz, Z. Olesinski, European Research Studies Journal, XXIV(2), 1149-1162 (2021)

68. P.W. Saługa, K. Szczepańska-Woszczyna, R. Miśkiewicz, M. Chłąd, Energies, 13(18), 4833 (2020)

69. H. Dźwigoł, Virtual Economics, 4(1), 98-117 (2021)

70. H. Dzwigol, Marketing and Management of Innovations, 1, 128-135 (2020)

71. H. Dzwigol, Academy of Strategic Management Journal, 19(4), 1-8 (2020)

72. H. Dzwigol, Marketing and Management of Innovation, 1, 324-335 (2021)

73. H. Dzwigol, R. Wolniak, Przemysl Chemiczny, 97(7), 1114-1116 (2018)

74. H. Dzwigol, S. Shcherbak, M. Semikina, O. Vinichenko, V. Vasiuta, Academy of Strategic Management Journal, 18(SI1), 1-8 (2019)

75. H. Dzwigol, O. Aleinikova, Y. Umanska, N. Shmygol, Y. Pushak, Journal of Entrepreneurship Education, 22(1S), 1-7 (2019)

76. H. Dzwigol, M. Dźwigoł-Barosz, A. Kwilinski, International Journal of Entrepreneurship, 24(1), 1-5 (2020)

77. Y. Kharazishvili, A. Kwilinski, O. Sukhodolia, H. Dzwigol, D. Bobro, J. Kotowicz, Energies, 14(8), 2126 (2021)

78. Y. Kharazishvili, A. Kwilinski, H. Dzwigol, V. Liashenko, Virtual Economics, 4(2), 740 (2021)

79. A. Kwilinski, O. Vyshnevskyi, H. Dzwigol, Journal of Risk and Financial Management, 13(7), 142 (2020)

80. O. Lyulyov, T. Pimonenko, A. Kwilinski, H. Dzwigol, M. Dzwigol-Barosz, V. Pavlyk, P. Barosz, Energies, 14(2), 373 (2021)

81. O. Lyulyov, I. Vakulenko, T. Pimonenko, A. Kwilinski, H. Dzwigol, M. DzwigolBarosz, Energies, 14(12), 3497 (2021)

82. H. Dzwigol, M. Dźwigoł-Barosz, Financial and Credit Activity: Problems of Theory and Practice, 2(25), 424-437 (2018)

83. A. Kwilinski, H. Dzwigol, V. Dementyev, International Journal of Entrepreneurship, 24(1 Special Issue), 1-5 (2020)

84. O. Arefieva, O. Polous, S. Arefiev, V. Tytykalo, A. Kwilinski, IOP Conference Series: Earth and Environmental Science, 628, 012039 (2021)

85. V. Boiko, A. Kwilinski, M. Misiuk, L. Boiko, Economic Annals-XXI, 175(1-2), 68-72 (2019) 
86. S. Bogachov, A. Kwilinski, B. Miethlich, V. Bartosova, A. Gurnak, Entrepreneurship and Sustainability Issues, 8(2), 487-499 (2020)

87. O. Chygryn, Y. Bilan, A. Kwilinski, Marketing and Management of Innovations, 3, 356-368 (2020)

88. N. Dalevska, V. Khobta, A. Kwilinski, S. Kravchenko, Entrepreneurship and Sustainability Issues, 6(4), 1839-1860 (2019)

89. V.V. Dementyev, A. Kwilinski, Journal of Institutional Studies, 12(1), 100-116 (2020)

90. V. Khrapkina, A. Kwilinski, J. Polcyn, K. Pająk, V. Stratonov, V. Kobets, V. Virtual Economics, 4(2), 41-73 (2021)

91. V. Koibichuk, N. Ostrovska, F. Kashiyeva, A. Kwilinski, Marketing and Management of Innovations, 1, 253-265 (2021)

92. V. Kondratenko, O. Okopnyk, L. Ziganto, A. Kwilinski, Marketing and Management of Innovations, 1, 87-94 (2020)

93. A. Kuzior, A. Kwilinski, V. Tkachenko, V. Entrepreneurship and Sustainability, 7(2), 1353-1376 (2019)

94. A. Kuzior, A. Kwilinski, I. Hroznyi, Energies, 14(9), 2572 (2021)

95. A. Kwilinski, Virtual Economics, 1(1), 7-25 (2018)

96. A. Kwilinski, Marketing and Management of Innovations, 4, 116-128 (2018)

97. A. Kwilinski, Academy of Accounting and Financial Studies Journal, 23(SI2), 1-6 (2019)

98. A. Kwilinski, V. Tkachenko, A. Kuzior, Journal of Security and Sustainability Issues, 9(2), 561-570 (2019)

99. A. Kwilinski, N. Dalevska, S. Kravchenko, I. Hroznyi, I. Kovalenko, Journal of Entrepreneurship Education, 22(SI1), 1-7 (2019)

100.A. Kwilinski, I. Ruzhytskyi, V. Patlachuk, O. Patlachuk, B. Kaminska, Journal of Legal, Ethical and Regulatory Issues, 22(SI2), 1-6 (2019)

101.A. Kwilinski, R. Volynets, I. Berdnik, M. Holovko, P. Berzin, P. Journal of Legal, Ethical and Regulatory Issues, 22(SI2), 1-6 (2019)

102.A. Kwilinski, K. Pajak, O. Halachenko, S. Vasylchak, Y. Pushak, P. Kuzior, Marketing and Management of Innovations, 4, 172-181 (2019)

103. A. Kwilinski, A. Kuzior, Management Systems in Production Engineering, 28(2), 119$123(2020)$

104.A. Kwilinski, Y. Zaloznova, N. Trushkina, N. Rynkevych, E3S Web of Conferences, 168, $00031(2020)$

105.A. Kwilinski, M. Dielini, O. Mazuryk, V. Filippov, V. Kitseliuk, Journal of Security and Sustainability Issues, 10(1), 345-358 (2020)

106.A. Kwilinski, D. Shteingauz, V. Maslov, Financial and Credit Activities: Problems of Theory and Practice, 3(34), 133-140 (2020)

107.A. Kwilinski, I. Slatvitskaya, T. Dugar, L. Khodakivska, B. Derevyanko, International Journal of Entrepreneurship, 24(1 Special Issue), 1-8 (2020)

108.A. Kwilinski, V. Litvin, E. Kamchatova, J. Polusmiak, D. Mironova, International Journal of Entrepreneurship, 25(1), 1-8 (2021)

109.Y. Kyrylov, V. Hranovska, V. Boiko, A. Kwilinski, L. Boiko, L. Journal of Risk and Financial Management, 13(12), 303 (2020) 
110.V. Lakhno, V. Malyukov, T. Bochulia, Z. Hipters, A. Kwilinski, O. Tomashevska, International Journal of Civil Engineering and Technology, 9(8), 1802-1812 (2018)

111.K. Pająk, B. Kamińska, O. Kvilinskyi, O. Financial and Credit Activity: Problems of Theory and Practice, 2(21), 204-217 (2016)

112.T. Savchenko, N. Basiurkina, O. Rodina, A. Kwilinski, Management Theory and Studies for Rural Business and Infrastructure Development, 41(1), 43-61 (2019)

113.V. Tkachenko, A. Kwilinski, O. Korystin, N. Svyrydiuk, I. Tkachenko, Journal of Security and Sustainability, 8(3), 375-385 (2019)

114.V. Tkachenko, A. Kwilinski, M. Klymchuk, I. Tkachenko, Management Systems in Production Engineering, 27(2), 119-123 (2019)

115.V. Tkachenko, A. Kwilinski, I. Tkachenko, P. Puzyrova, Marketing and Management of Innovations, 2, 228-238 (2019)

116.V. Tkachenko, A. Kwilinski, B. Kaminska, I. Tkachenko, P. Puzyrova, Financial and Credit Activity: Problems of Theory and Practice, 3(30), 85-94 (2019)

117.V. Tkachenko, A. Kuzior, A. Kwilinski, Journal of Entrepreneurship Education, 22(6), $1-10(2019)$

118.J. Polcyn, Sustainability, 13(15), 6846 (2021)

119.L.M. Karpenko, M. Serbov, A. Kwilinski, V. Makedon, S. Drobyazko, Academy of Strategic Management Journal, 17(5), 1-7 (2018) 